\title{
1. The state and societal change after the Napoleonic Wars
}

\subsection{INTRODUCTION}

In Europe the role of the 'state' is often considered to have been minimal during the 19th century. It has been called the 'night watchman state' regulating society by means of its core activities: securing sovereignty (including the defence of the realm), maintaining law and order in its territory, and collecting taxes to pay for its administrative and judicial apparatus, in particular the military. In fact, this idea is a myth or, put differently, a grave misreading of history (Romein, 1967: 336-9; Tilly, 1975; Van der Woud, 2007: ch. 3; Benz, 2008: 34). The post-Napoleonic era not only led to the emergence of 'national' states (and colonies), but also to a growing bureaucracy regulating society in the name of the Head of State, more often than not a monarch in the 19th century.

The origins of this myth of the night watchman state lie in the ahistorical ideas of many social and economic scientists who mistook economic growth due to industrialization and international trade to be the sole result of private capital and energetic entrepreneurs. Although this did mean a leap in the architecture of the economy, it also affected significantly the role of the state in Europe (Taft Morris and Adelman, 1988; Hobsbawm, 2012: 41-6). One of the main effects has been the growth of public spending and revenues and the urge for active state intervention to provide 'public goods' to correct 'market failures' or to provide services for the benefit of the 'wealth of the nation' (Olson, 1982: 42-3).

Infrastructure, for example, became a priority, facilitating new developments in transport, first in canal systems and later in railway networks and communication by telegraph in the 19th century. Often these endeavours took the form of a public-private partnership (Millward, 2005: 59-61; Van der Woud, 2007: 130-36). Hence, increasingly the state was seen as the centre of action or at least as a necessary 'brother in arms' enabling the Industrial Revolution to take off.

In particular, the interdependence of several layers of the state, economic developments and concomitant social change necessitated the regulation of 
the public domain in order to address collective problems. Industrialization, urbanization, growing markets and affluence - albeit disproportionally distributed - led to new demands across populations in a modernizing society, a society that simultaneously, albeit slowly, was democratizing (Bermeo and Nord, 2001). The revolutionary impact of mechanizing production and the corresponding need for infrastructural developments, transportation networks in particular, and public regulation created a new challenge to the state (Olson, 1982: 126-7). Instead of a 'minimal state' it became nolens volens a 'regulating state'. As Strayer (1970: 110) concludes: “. . . Western European states had developed their own characteristic political patterns, the patterns that determine the structure of most states today."

As will be elaborated in Chapter 2, the revolutionary impact of steam power propelling industrialized manufacture not only opened up new ways of economic activity but also meant a profound change in the modes of transport of people and commodities (Habakkuk and Postan, 1966 (Volume VI): 230-42; Cipolla, 1973 (Volume 2): 688ff.; Casson, 1998). This technical revolution not only concerned the mere use of steam power by means of trains, but also innovative engineering in surveying routes and laying tracks, digging tunnels, constructing bridges and dealing with the state in gaining consent to use the public domain by means of concessions (Talbot, 1911). Hence, the role of the nation state in the 19th century extended profoundly, and state officials had to deal with many new issues.

Just imagine how state officials must have reacted to proposals to build railway tracks and use steam-powered vehicles to pull trains across open areas - never before had the state administration been confronted with such matters. For example, what would this mean in legal terms (e.g. property rights and the public domain)? What if the land used was owned by the state or was private? What type of concession was to be drafted to safeguard the state's interests? Other questions raised were: How would this new invention affect the environment? Was it dangerous or not for people, buildings and animals? How did the laying down of tracks affect the architecture of military defence? Further, there were political queries as well: Who or what institution was responsible for administering this development and monitoring its effects for the good of society? What was considered to be the public domain and what were the collective needs to use it? All these questions regarding the role of the state were crying out for an answer and have been answered differently by economists, historians and jurists (Supple, 1963; Tilly, 1975; Mayntz and Hughes, 1988). In short: the fate of the state was invariably to intervene in society! 


\subsection{TOWARDS THE INTERVENTION STATE}

This book sets out to analyse the role of the emerging 'modern' state as administrator of its territory, as regulator of its infrastructure and (often) as co-financer-cum-investor. This is an exciting exercise because it allows for a cross-time comparative analysis of the emerging democratic states. For exactly during the era of 'steam', political institutions were developed to democratize the polity: certainly after the revolutionary year 1848 when electoral participation was slowly extended (for the middle classes only), responsible government developed (parliamentary control was introduced), and the 'Rule of Law' was not only adhered to by authorities but also became a genuine instrument of 'public regulation' (Bermeo and Nord, 2001). Hence, our analysis of the transport revolution in the 19th century of the developing railway systems in particular has had ramifications for state action and organization. This book therefore implies a tour d'horizon in how the intervention state originated and - in our view - is still shaped accordingly in its present organization, institutions and capacities.

Altogether this view also implies that - given the concomitant process of democratization - we assume that 'politics matters' as regards the role of the state in shaping society (Schmidt, 1996; Keman, 2002; Castles, 2007). The role of the state was to respond and to react to the dramatic socioeconomic changes in society (see e.g. Hobsbawm, 1968; Romein, 1971; Finer, 1997: 1583-94; Fukuyama, 2014) by means of public policy formation. For the process of industrialization not only brought about more production (by mechanical means) and trade (due to transport), but also led to urbanization (and a growing middle class), concentration of the means of production (industrial capitalism) and a concomitant growing working class (gradually organized in emerging trade unions), internationalization of trade, competition between states and a colonial race for resources (and imperial ambitions, especially on the part of France, Russia and the UK). As Hobsbawm (1968: 54) writes:

The final characteristic of the economy [. . .] is the growing convergence between politics and economics, that is to say the growing role of government and the public sector [ ....] after 1875, there was growing scepticism about the effectiveness of the autonomous and self-correcting market economy, Adam Smith's famous 'hidden hand', without some assistance from state and public authority. The hand was becoming visible in all sorts of ways.

In other words, the 19th-century state clearly played increasingly an interventionist role in the development of society. In particular, infrastructure and transport became important collective goods and an assignment of states - internally and externally. Steam, railways and telegraph communications 
rapidly turned out to be essential in this process of what we would call now 'globalization' It led to the widening of markets, the shrinking of distances and travelling time, growing consumption and more leisure time. If our view is correct, it is difficult to consider the 19th-century state merely as a 'night watchman' - on the contrary! The modern, or better perhaps, the contemporary state, so we argue, basically originated and developed in the 19th century. Yet, many political scientists have ignored and neglected this process of state formation and its related consequences for the study of state-society relations.

How has this happened? First of all, post-war political science - say during the 1950s and 1960s - focused mainly on political behaviour and electoral processes in order to assess how political stability of post-war democracies could be achieved and maintained (Finifter, 1993). After the so-called 'behavioural revolution' (see Easton, 1981) a revival of the institutional approach occurred in the USA and Europe (Keman, 1998; Rhodes et al., 2008). Whereas the European debate on the state was conducted by neo-Marxists (like Offe, Habermas and Poulantzas) and those following the approach developed by Max Weber (Giddens, 1971; Benz, 2008), on the other side of the pond ideas were developed by the 'pluralists' (Nordlinger, 1981; see also C. Pierson, 2011: 89-96) and by historical sociologists (Skocpol, 1979; Rokkan, 1999). We shall not dwell on this debate here (for an excellent overview, however, see Held, 1983: 32-43), but it is clear that the concept of the 'state' was brought back in again in the discourse of political science as if it had been away in reality.

Remarkably enough, at the same time debates began on the emergence of 'globalism', what would or at least could imply the end of the national state (C. Pierson, 2011: 182ff.). National borders and territorial authority would become outdated and statist jurisdiction and competences obsolete. In particular the development of the EU (formerly EEC and EC) would signify the 'denationalization' of the state. Zürn (2005) argues that European integration is increasingly affecting the policy competences and the autonomy of the traditional state. Scharpf (1988), however, points to a 'joint-decision trap' due to the two-level game played simultaneously on the national and transnational level, often constraining policy actions on both levels.

This latter point can be illustrated, for example, by the role of the EU as a transnational agent: whilst the care of infrastructural needs had been considered as one of its prime assignments as early as 1961, hardly anything was happening up to the late 1980s. Hence, whatever the process of globalization may be in reality, it appears that the national state and related political actions are still decisive as regards shaping society. Nevertheless, and in addition to our main thesis on state formation and concomitant modes of intervention, we shall analyse in this book the growing influence of the EU on the politics of transportation (Stevens, 2004). 
To conclude this section: whatever the future of the 'state' is, what remains puzzling is that many political scientists and economists do not consider the state as a central topic of research, but rather see it as a contextual variable representing how governance is organized (Easton, 1981; but see also Keman, 1993; C. Pierson, 2011). However, we argue that the study of the emergence of the nation state and its development towards democratization in the 19th century is essential to understand its contemporary institutional form (competences) and capacities (policy formation) to intervene in shaping society in general and its infrastructure in particular.

\subsection{THE STATE AND THE NATION}

In this book the contemporary state is conceptualized as a diachronic variable, meaning that - dependent on context (history, geopolitical location, size and resources) - the state has developed over time its format and capacities. Crucial in this development has been the acquisition and centralization of power resources (Engels, 2015 [1884]; Tilly, 1990). In many studies of the state, its form is linked with socioeconomic structure (e.g. with industrial capitalism) and socio-cultural features of society (Tilly, 1975; Finer, 1997; Rokkan, 1999). This development is particularly evident in Europe: war and peace alternated, and trade, religion and royal marriage shaped in large part the geopolitical map of Europe during the 16th and 17th centuries. It was the period when absolutist rule - or, as Weber coined it, the Patrimonial State (cf. Weber, 1972 [1922]) - prevailed whereby public authority became more than less centralized (law and order, uniform taxation and territorial regulation) and bureaucracies were responsible for the running of the state apparatus and indispensable for regulating society (Anderson, 1975; Lane, 1993; Rokkan, 1999: 232; Benz, 2008: 96ff.; Fukuyama, 2014: 54-9).

Yet, the political revolutions taking place in North America and France (Hobsbawm, 1962; Skocpol, 1979) represented a watershed in many ways because of the introduction of constitutionalism (governance by law), standardization of language and economic life (e.g. education, currency and contracts) and the emergence of nationalism to unite the population under the public authority of the state (being conducive to inclusion of people, i.e. citizenship of inhabitants within a territory). According to Gellner (1983) and Hobsbawm (2012) these processes run parallel and interact with each other in the 19th century, leading to the national state. After the Napoleonic Wars and the restoration of the ancien régime, the geopolitical map was drawn as territorial states in Europe which - albeit in differing forms and timeframes became eventually what we consider to be nation states (Rokkan, 1999: 68-9).

In short, what was originally an ethnically, religiously and linguistically heterogeneous population in a territory developed through numerous contin- 
gencies (royal marriage, conquest by neighbouring rulers, inheritance, etc.) gradually grew into a 'nation' by means of a common set of values, symbols, myths, heroes and memories. The standardization of mental norms, as it were, aided by the eventual standardization of language, helped to engender a consciousness of belonging to a 'nation'. Furthermore, by centralizing and unifying administrative processes, introducing compulsory mass education and military service (conscription), and forging a common economic area, the state was able to assert the idea of sovereignty over particularistic forces arising out of regionalism and the persistence of traditional social order (Teichova and Matthis, 2003: 1-2; Huntington, 2006 [1968]; Hobsbawm, 2012). Instead of 'patrimonial' coercion designed simply to make a citizen comply, a shared identity invited individuals to be loyal and dutiful (Strayer, 1970: 111).

Nation and state became twins. Arthur Benz (2008: 33) writes: "Staat, Volk und Nation verschmolzen zu einer Einheit. Eine Nation ohne Staat galt als Anachronismus, ein Staat ohne Nation als illegitim.' This political idea of nation and state as a symbiotic relationship had also a more romantic or emotional aspect. For example, Hobsbawm (2012: 10) (following Gellner) defines the term 'nationalism' as

... primarily a principle which holds that the political and national unit should be congruent. I would add that this principle also implies that the political duty of Ruritanians to the polity which encompasses and represents the Ruritanian nation, overrides all other public obligations, and in extreme cases (such as wars) all other obligations of whatever kind.

Nation and state not only became almost, if not fully, synonymous, but also the state and the 'people' became mutually dependent (Romein, 1967: 128-9; Fukuyama, 2014: 192-5): socioeconomic development and the national economy were part and parcel of the state's assignment per se. Hence, politics and economics obtained a central position in Western societies when mechanical power profoundly changed the economy and society. One of the core assignments of the nation state was therefore to monitor and promote the development of infrastructure within the territory that would facilitate the process of industrialization to engender the 'wealth of the nation' if not the 'common good'.

\subsection{THE STATE AND THE ECONOMY}

The existence of the nation state is clearly developed in the 19th century. By and large, it is accepted that its emergence can be seen as an interaction of economic, political and ideological forces in which national interests played a significant role. Central is the idea that the common good is a common inter- 
est that must be enhanced and organized by means of public authority which is vested in the state acting for the nation. Recall that - among other things - this era is characterized by a strong correlation between industrialization and the need for transport (Teichova and Matthis, 2003). As we know, transport means connecting commodities to markets (be they producers or consumers). This implies that the provision and maintenance of roads, waterways and security (policing rules) was essential. The state was there to oblige or at least to facilitate this, for instance by abolishing tolls and turnpikes, maintaining public ways and waterways, and to allow for railways as a public utility.

The revolution of transport by means of steam power and, from the 1840s onwards, the telegraph, did indeed change the role of the state in society: in functional terms the state could develop its mastery over society by integrating the periphery and thereby uniting society from one 'centre of power' (i.e. national government). Secondly, it implied that rules and institutions were upheld throughout the territory and applied to all citizens equally (police and bureaucracy). Conversely, society slowly but distinctively penetrated the state by means of interest representation (national parliament), on the one hand, and the institutionalization of 'responsible government', on the other hand (see Keman, 1993; Rokkan, 1999). This dialectical development is important to note for our story: it signifies that the maturation of the 'modern' or contemporary state originated in the 19th century. Hence, the state intervened in society and thereby shaped the socioeconomic context contrary to widely held views in the literature.

Another aspect of industrialization and new forms of transport was, in addition to economic growth, the creation of nationwide markets as well as the internationalization of trade. The role of the state was, again, important: geopolitical policies in terms of colonialism and opening up other markets (by diplomacy or military force) became instrumental to further the national interest and pride (Taft Morris and Adelman, 1988; Hobsbawm, 2012). Industrial capitalism and state intervention concurred in creating 'modern' society (Fukuyama, 2014: 202-4). This interactive evolution led to many debates among politicians and economists on when, how and why the state would or should intervene in society (Keman, 1993; C. Pierson, 2011). On the one hand, this concerned taking care of the fate of the poor, [ regulation of safety in industries (labour), and responding to the effects of urbanization (housing and hygiene). This type of state intervention signified the birth of the 'social welfare state' (Keman, 2017: ch. 6). On the other hand, the role of the state was considered that of protecting national economic interests (by force if necessary). Two directions prevailed: (1) to promote 'free trade' and (2) if and when there were fewer comparative advantages, protectionism. Hence, the core of the state, nationally organized and responsibly governed, should be considered as an 'intervention state' rather than as a 'night watchman state' (or 
minimal state) assisting as ultima ratio in national economic interests. As Eric Hobsbawm (1968: 54) noted:

The final characteristic of the economy [. . .] is the growing convergence between politics and economics, that is to say the growing role of government and the public sector [.. .] there was a growing scepticism about the effectiveness of the autonomous and self-correcting market economy [. . .] without some assistance from state and public authority.

What does this observation signify for the development in infrastructure in the industrializing nations in the 19th century? Firstly, the state interfered in regulating the use of land and the emission of concessions (in respect of private capital initiatives - which more often than not was the case). Secondly, the strengthening of democratic institutions leaning on the Rule of Law guaranteed and protected private ownership (property rights) by the state. Thirdly, emerging institutions, such as banks, were monitored allowing them to gather capital pools and invest them in economic ventures. Hence, the process of capital accumulation and allocation became increasingly rationalized and institutionalized. This stimulated new private capital initiatives often backed by the state by means of additional financial support or loan guarantees. This latter practice occurred often in continental Europe with regard to, for instance, canal systems, railways and the telegraph. Fourthly, the development of mechanized transport systems required public regulation of road construction and traffic rules, and monitoring and organizing canal systems supporting the distribution of resources and trading routes (see e.g. Van der Woud, 2007: 164-6). Markets could interact more effectively, both nationally and internationally (Rodrigue, 2017) by means of the national state. In a study of the development of state capacities in relation to economic growth Johnson and Koyama (2016) conclude: "Various studies have attempted to quantify the extent of market integration in early modern Europe. This research shows that, in general, markets only became fully integrated in the nineteenth century" (emphasis added).

All in all, the national state and economy not only interacted more and more, but were also increasingly guided through the (slowly democratizing) politics of interest representation. State and society became increasingly interdependent (Romein, 1967: 333; C. Pierson, 2011: 91-104), especially so with respect to the development of the territorial infrastructure that accelerated socioeconomic change. 


\subsection{STATE AND SOCIETY: THE WEALTH OF NATIONS}

In many economic growth models, infrastructure is one of the main conditions to explain the economic development of a nation. Fukuyama (2014: 44), referring to Adam Smith, tells us:

But there would be no incentive to increase productivity, [ . . . if a sufficiently large market did not exist. Smith thus argues that the expanding division of labor is stimulated in turn by improvements in transportation and communication that increase the size of markets.

There are several models that seek to explain the main factors for economic growth, but only the so-called exogenous ones include variables that go beyond capital accumulation and labour productivity. For example, the Solow-Swan model conceptually defines technological progress (based on two endogenous factors - research \& development and education) as a prime factor in addition to capital accumulation and labour power. Hence, enhancing productivity by means of new innovations and applications in the second half of the 19th century, like railroads, steam ships, harvesters and steam-powered factories, boosted economic growth in the UK and not much later in Germany, France, Belgium and the Netherlands (Cipolla, 1973). The invention of processes for making steel instead of using pig iron were crucial for many forms of mechanization and transportation. As David Landes (1969: 3) argues:

In this sense, the Industrial Revolution marked a major turning point in man's history. To that point, the advances of commerce and industry, however gratifying and impressive, had been essentially superficial [. . .]. It was the Industrial Revolution that initiated a cumulative, self-sustaining advance in technology whose repercussions would be felt in all aspects of economic life.

In other words, most econometrists as well as many economic historians contend that the Industrial Revolution signified a big leap forward in economic development and concomitant growth. The unique quality was that this 'Big Push' (cf. Johnson and Koyama, 2016) was mainly due to large investments in infrastructure and improvements in education coupled with private initiatives. It was the public sector - organized through the nation state - that helped this process, for example, by means of market regulation, government bonds, loans or backing-up financiers, on the one hand, and developing technological skills by modernizing education by means of extended and specialized schooling, on the other hand.

This change in context moved the market economy to a more productive stage and larger markets. Oddly enough, in most models of economic growth 
the role of the state is not mentioned or remains hidden behind the abstract notion 'institutions' as an exogenous variable (but see Taft Morris and Adelman, 1988; North, 1990; Maddison, 1991: 43-7). Where economists use the term institution, political scientists employ the terms state and governance to depict the architecture and working of a political system. It is a configuration of rules and conventions defining the operations of political and societal actors within (bureaucracy) and under the aegis of the state (Keman, 1993; Moran et al., 2008). This implies that the institutions an economist refers to must be defined as the 'output' of the state, i.e. public policy (Mayntz and Hughes, 1988).

Obviously, the role of institutions produced by government are relevant for economic development and concomitant growth (Landes, 1969). In fact, it creates the room to manoeuvre for citizens to prosper economically. Without the state this is difficult, if not impossible, for it appears unlikely that a state will generate institutions that respect property rights and the Rule of Law without having had first intermediate fiscal and political institutions that create incentives for elites to support them, instead of relying on rent-seeking (Olson, 1982: ch. 5). Originally, many of these intermediate-level institutions relied on informal private-order arrangements (like the Hansa Alliance or chartered overseas companies in pre-modern times) that combined with public-order institutions associated with governance to lay the foundations of modern 'Rule of Law'. Hence, just as society impacted on the state, so the state increasingly impacted on economic life (Romein, 1967: 333ff.; Keman, 1993: 194ff.; Fukuyama, 2014).

State capacities and effective government - typically characterized by bureaucracy - are thus conditions for variations of economic growth and are, in our view, part and parcel of analysing economic development (Weber, 1972 [1922]; Maddison, 1991: 113). State capacities refers to yielding positive tax returns (revenues), maintaining the law (safety and security), providing stability of market transactions (including monetary policy) and providing an infrastructure that integrates national markets and secures international trading. Yet, effective government also implies nation-building. Without this, it appears almost impossible to develop civic compliance by abiding to state regulations based on legitimacy:

[...] a flourishing and rich civil society was both a prerequisite for successful state development and an important complement to it: [the] capacity of the state and the organization of society fed on each other in a synergetic way. (Acemoglu and Robinson, 2014: 15)

The long and the short of it is that economic models accounting for economic development and eventual prosperity may well explain long-term growth, 
but they have certain shortcomings. Firstly, the general models (although some are empirically evidenced by means of time series analysis) show large residuals that are often 'explained away' as 'steady state' developments (i.e. unexplained variance is seen as ceteris paribus where there is zero-growth or development). To quote Johnson and Koyama (2016): "For a closer picture we need more micro-level historical studies and we need to pay attention to the mechanisms and channels linking a history of statehood to modern outcomes."

Secondly, endogenous models like the Solow-Swan model and others ignore many factors that may well impact on economic developments in different countries over time, like the emergence of national states in Europe (socioeconomic standardization and bureaucracy), and the institutions shaping state-society relations and political regimes (representative government, state capacities and effective governance). As we shall see in Chapter 2 the extent of providing public goods (like infrastructural needs, safety and security, macroeconomic management and industrial policy, etc.) effectively by the state is in large part dependent on the scope of state functions which in turn depends on the extent of an enforceable and legitimate institutionalization (see also Keman, 1998; Fukuyama, 2014: 52-9).

Thirdly, and obviously, as is asserted by a number of economic historians, the (albeit slow) process of democratization and growing formation of state capacities plays a crucial role in our study of infrastructural development. David Landes (1969: 548-9) writes accordingly:

. . . even a cursory consideration of the comparative government of industrialized and industrializing nations makes it clear that a wide variety of institutional arrangements have been compatible with this course of development. [. . . There was as much intervention in the economy: security, first, in the widest sense that transcends mere physical safety of persons and possessions and implies the ability to assume the working out of economic decisions without arbitrary non-economic interference - no security, no prediction; and second, effective management of the affairs of government.

Social and political stability, predictability in terms of accepted rules of economic behaviour and, last but certainly not least, effective state capacity can therefore be considered as vital exogenous ingredients for understanding the 'big push' in economic development across Europe, America and Australasia in the 19th century.

Finally, in most studies on economic development and growth, the role of transportation and its infrastructure is stressed as a sufficient and necessary condition for change. This idea implies that one can distinguish between a contingent condition and a required condition of a process. Hence, sufficient conditions can be interpreted as causalities explaining the diversity across cases, whereas necessary conditions often explain a convergent development. 
In our case, the expansion of railway networks and their usage for transportation knows sufficient and necessary elements. This distinction is relevant for understanding the role of the state (providing public goods) and, of course, its economic utility (backward and forward linkages) and social spin-off (e.g. passenger transport for commuting) - in short, transportation as a 'common good'.

Transportation by train is, so we argue, therefore an excellent case: it illustrates the technological advent of transportation during the Industrial Revolution as well as its effects on economic development and social spin-off. In addition, it allows us to analyse the role of the state in relation to socioeconomic evolution more deeply. Further, it will help us to understand better the politics of infrastructural planning and development in a democratizing society in the past. Recall that the main thesis of this book contends that the present democratic state originated in the 19th century and that its fundamental structure is basically still apparent in the present in terms of intervention by means of policy formation. Yet, its formal organization and institutions have remained essentially the same. So the contemporary state can be viewed as an extended version of the 19th-century state.

In the next chapter we will elaborate the case of transportation and in particular railway development in more detail. Our argument will be shaped by using a refined and adjusted approach of political economy. However, before this, the methods of analysis used will be outlined, as well as the plan of the book.

\subsection{POLITICAL SCIENCE AND HISTORY}

The 'art' of history is considered by many as a close companion to political science. As the British historian Sir John Seeley once wrote: "History without political science has no fruit, political science without history has no root." Hence there appears to be a natural relationship between the disciplines. Historical accounts and analyses offer rich information and empirical evidence on our 'past'. This can be and is used by political scientists to validate their research and to develop their theories. Conversely many historians have also made good use of concepts and ideas developed within the social sciences and political science in particular.

The British historian E. H. Carr wrote a book titled What is History? He emphasized that historiography was the key to understanding historical developments. 10 In fact, he urged that 'facts' in history could always be contested for two reasons: they are constructs as interpreted by the observer, and thus are, at best, relatively true. In addition, Carr considered history to be a part of the social sciences (Carr, 1990 [1961]: 181-2).

Historical research has often concerned itself with 'big questions' like the causes of revolution (Skocpol, 1979), the breakdown of democracies 
(Barrington Moore, 1966), or the emergence of the (national) state (Tilly, 1990; Benz, 2008). However, it does not signify that political historical analysis only seeks to develop comprehensive explanations. In short, comparative historical analysis is an important asset in relating political science to history as an approach to describe and explain change in society. As Charles Tilly (2009: 536) puts it: "Every significant political phenomenon lives in history and requires historically grounded analysis for its explanation." By identifying causal configurations, the researcher is capable of developing theory that is conducive to explaining outcomes (Keman, 2013). Secondly, by unfolding the temporal structure of events, a systematic comparison becomes meaningful (Flora and Heidenheimer, 1981). Thirdly, by choosing deliberately comparable cases, e.g. 'most similar' or 'contrasting cases', the researcher is able to explore contextual variation.

For example, in 1968 Nettl wrote an intriguing essay on the 'stateness' of societies as a conceptual variable. His idea was that public authority became increasingly 'politicized' due to changing societal demands, on the one hand, and because industrialization and infrastructural development required a more active state, on the other hand. Owing to the different historical paths taken by evolving governmental systems, continental Europeans think of 'sovereignty' as residing in centralized administrative institutions, whereas Britons focus on political parties in Parliament and US citizens refuse to designate any concrete body as sovereign, but instead attribute sovereignty to the law and the Constitution. In Europe, according to Nettl, the administrative order is instantly recognizable as an area of autonomous action, and both supporters and opponents of the existing order orient themselves to working through it as the agent of the common good.

To view 'stateness' as a process whereby the relations between state and society emerge in conjunction with the process of democratization and industrialization can be considered as a configuration of functions, institutions and roles over time (Mahoney and Rueschemeyer, 2003). This type of research is what we intend to employ in this book by analysing the role of the state in terms of its intervention by means of public goods with regard to transport, in particular the development of railways during the era of 'industrial revolution'. As already put forward, we assume that the configuration of national states will differ over time and space, but we expect that the contemporary democratic state has converged into a more similar than different phenomenon in the Western world.

Our examination of this thesis will be developed by means of comparative historical analysis in order to create a more heuristic and descriptive account regarding state and nation formation (Tilly, 1975; Skocpol, 1985; Hobsbawm, 2012), state intervention (North and Thomas, 1973; Fukuyama, 2014) and the 
development of state capacities (Weber, 1972 [1922]; Johnson and Koyama, 2016). Theda Skocpol (1985: 33) wrote in an essay the following sage words:

As we bring the state back in to its proper central place in explanations of social change and politics, we shall be forced to respect the inherent historicity of sociopolitical structures, and we shall necessarily attend to the inescapable intertwinings of national-level developments with changing world historical contexts. We do not need a new or refurbished grand theory of 'The State'. Rather, we need solidly grounded and analytically sharp understandings of the causal regularities that underlie the histories of states, social structures, and transnational relations in the modern world.

Hence, comparative historical analysis not only puts flesh on the bones of theory, but also makes clear that political theories often need refinement and contextualization (Landes, 1969; Anderson 1975) in terms of sequencing using time and space together (Bartolini, 1993; Mahoney and Rueschemeyer, 2003).

To this end we will make use of different methods that have been developed in both disciplines, like the use of quantitative history or 'cliometrics' (Floud, 1973), and discuss the application of counterfactual analysis (Ragin, 2000). Counterfactual analysis or 'iffy-history' aims at explaining historical outcomes by hypothesizing alternatives by means of statistical analysis and has been used for analysing the impact of the railway revolution (O'Brien, 1977). Another type of analysis is the idea of path dependencies: events or decisions made in the past define and often limit the room for manoeuvre in the future. There is no point of return to the former situation or the possibility to make drastic changes (e.g. explaining 'policy inertia'; see Lane, 1993; P. Pierson, 2003). For instance, once railways were introduced their infrastructure was designed to be(come) and became an almost exclusive alternative to extant means of transportation. Historical analysis can also be employed to verify the impact of critical junctures: an event or series of (more or less simultaneously occurring) events that is seen as a fundamental change in society - like the Industrial Revolution or a political revolution - and thereby shifting the historical context and the role of the nation state forever.

In sum, in this book we will use history as a source of evidence by means of secondary information (i.e. second-hand evidence derived from publications, memoirs, statistics, etc.) and we will depart from the comparative approach used in political science in terms of diachronic analysis. 1 We are convinced that this approach is the best way to go. 


\subsection{PLAN OF THE BOOK: STATISM AND TRANSPORTATION}

The main thesis we entertain throughout this book is that the contemporary (nation) state has its organizational and institutional roots in the 19th century, due to the accelerated development of the industrial capitalist system (mainly in Europe); effective government of society required not only a strong state, but also the development of its capacities to intervene in society by means of regulation, revenues and expenditures. The structure of government nowadays is deep down still the same in terms of organizational apparatus, political choice and regulating powers.

In this chapter we have outlined, in a cursory fashion, this process of how interactions between state, nation, economy and society were shaped and developed over time. We aim thereby to answer the question begging for an answer, to what extent the history of the contemporary state can indeed assist us to understand and evaluate its role in society. Our focus on transportation, in particular the case of the railways, is useful to explore more specifically the interaction between the state, economy and society.

This study contains two parts: Part I continues with Chapter 2: 'Industrial Revolution: Technology, Transportation and the State', in which we will delve into the nature and development of the technological revolution, known as the 'steam era'. In order to understand the relationship between the role of the state and socioeconomic change, we advance an adjusted theory of 'public goods'. This approach allows for an inspection of the triad state-economy-society showing why the state must inevitably intervene in the national economy.

In Chapter 3: 'State and Society: Railways and Economic Development', we shall present an overview of the growth of the industrialized economy and of the public sector. This enables us to inspect the relationship between 'statism', 13 socioeconomic development and the role of transportation in the course of the 19th century up to the present. Interdependence is here the key term to understand this process and actually implies a 'captured state', i.e. state and political governance tend to follow as well as guide socioeconomic development within a capitalist society (Shonfield, 1969).

In Chapter 4: 'The Captured State: How to Save the Train as a Collective Good' the focus moves towards present-day public expenditures and types of regulation by the state, illustrated by contemporary levels of state support, like subsidies and investment, to the infrastructure. This exposé serves to indicate the trade-off between the core state ${ }^{14}$ and the growth of welfare state expenditures after the Second World War. We argue that this trade-off has affected the role of the state regarding the operation and care of infrastructural needs by economizing and deregulation (Keman, 2011). 
Finally, in Chapter 5 of Part I: 'New Solutions for an Old Problem: Mixing Public and Private Goods', we set out to discuss a different exogenous variable: the emergence of transnational cooperation and related effects on national policy formation. We argue that the national state is partly 'denationalized' due to the emerging effects of globalism. The response has been dialectical: to save the 'captured state' and its capacities to intervene in society appears to be possible only by means of creating collective goods that go beyond the nation state. This chapter will therefore focus on the role of the European Union in relation to transport and the transnational coordination of the European railway system.

Part II of the book focuses on the relationship between railways as a pars pro toto of infrastructural development and the ways the state is involved in this process. It comprises four chapters presenting case studies of, respectively, Australia, Italy, Belgium and the Netherlands. The reasons for this choice are that each case is more than less unique but also touches on similar elements discussed in Part I. The Introduction to Part II will enlighten these arguments about why we chose these cases and what they have and do not have in common from a comparative perspective.

In the concluding Chapter 10, we will discuss the findings of both the general analysis as well as the case studies in view of our contention that the Industrial Revolution in the 19th century has had serious ramifications for the development and role of the state intervening in society by means of a variety of so-called 'public goods', especially so for the transportation infrastructure of nations.

Finally, our analysis arguably demonstrates that the contemporary state, however 'big' it may have become, has inherited its present organizational form and state capacities as shaped in the 19th century. This conclusion signifies also that the present problems of 'governance' are the result of a system of state management institutionalized in the 19th century: inefficient forms of public goods resulting from political decision-making often leading to policy failures.

Yet, the eventual partial denationalization of state capacities and devolution of operational management of public assignments continued, and was, if anything, reinforced. As will become clear throughout our story, there remains a perennial tension between democratic policy formation and achieving public welfare for all. The evolution of railways as a societal asset appears to be a striking example of these tensions par excellence.

\section{NOTES}

1. For example, Wagner's Law, which postulates that there is a strong correlation between economic growth and public expenditures. Although later criticized and 
amended by, for instance Peacock and Wiseman (1967), who claimed that shocks like war and economic depression have accelerated the growth of the public sector. The levels reached after the shock by and large remained. Hence, the level of public expenditure stepped up in the long run (Maddison, 2003: 59-61). This debate on the growth of state involvement and related expenditures will be further discussed and elaborated in Chapter 3.

2 Obviously, the internal organization of the contemporary state has certainly changed in format or size, instruments and working as an apparatus, but we contend that the structure is by and large identical and still founded upon the Weberian definition of the state. See Held (1983); Keman (1993: 180-82).

3. Presently, globalization is considered as the internationalization of socioeconomic processes. For instance, Manfred Steger (2009: 11) defines globalization as follows: "In general, globalization may ultimately reduce the importance of nation states. Supra-national institutions such as the European Union, the WTO, the G8 or the International Criminal Court replace or extend national functions to facilitate international agreement." However, we argue that the internationalization of economic processes like investments, production and with respect to trade, communications and colonialism is not a recent development but was also apparent around the turn of the 19th and 20th centuries. Although different in outlook, the similarity is due to technological developments that made international transport and communications possible and effective. Only the explicit transnational institutionalization of international cooperation was not yet apparent before the First World War. See Bordo et al. (1999).

4. "State, People and Nation converge to one entity. A nation without a state is an anachronism, a state without a nation is illegitimate" (own translation).

5. Ruritania is an imaginary Kingdom of central Europe, the setting of several novels by English novelist Anthony Hope (1863-1933) where love, passion and intrigue for the Fatherland were dominant values.

6. Note, for instance, that English-speaking nations often use this term in their official name; Australia, for example, calls itself The Commonwealth of Australia. Some states within the USA also use this term.

7. In the UK there was at that time a drastic solution, namely deporting the poor, vagabonds and petty criminals to Australia (Hughes, 2003). Another escape route was often emigration from Europe to the 'new' world.

8. An example is the development of extended education in the Netherlands in the 19th century. After 1860 the Dutch government founded academies for engineering (Delft and Twente) and economics (Rotterdam and Tilburg), and secondary schooling for training in languages, trade and commerce, and technical skills (nationwide).

9. Over long periods of time, even small rates of growth, such as a $2 \%$ annual increase, have large effects. For example, the UK experienced a $1.97 \%$ average annual increase in its inflation-adjusted GDP between 1830 and 2008. A growth rate that averaged $1.97 \%$ over 178 years resulted in a 32 -fold increase in GDP by 2008. See R. Thomas and S. H. Williamson, 'What Was the U.K. GDP Then?', Measuring Worth, 2018: http://www.measuringworth.com/ukgdp/ (accessed 12 April 2018).

10. Like methodology in the social sciences it concerns the critical assessment of the validity and reliability of the evidence and sources reported, the interpretation of the events analysed, and conclusions drawn. 
11. Black and MacRaild (2007: 125) provide this definition: "It is, at the very root, the idea of conjecturing on what did not happen, or what might have happened, in order to understand what did happen." The method seeks to explore history and historical incidents by means of extrapolating a timeline in which certain key historical events did not happen or had an outcome which was different from that which did in fact occur.

12. Two-dimensional analysis re. time and space. This is relevant if one undertakes comparative case analysis for the conditions, and contexts are often different from one case to another. See Keman (2013).

13. The term 'statism' is used by us to refer to market economies with active forms of government intervention and regulation influencing the market or mixed-market economy. It is assumed that the state has a legitimate and necessary role within the framework of a capitalist economy by intervening in markets, regulating the private sector industry and either providing or subsidizing goods and services not or inadequately produced by the market.

14. The core state is a construct developed by a research group organized by the University of Edinburgh (Castles, 2007). The core state concerns those functions and expenditures that are central to the state like Justice, Defence, Police, Foreign Affairs, the Interior, and Infrastructure. The other functions like Health Care, Education, Employment, Environment etc. are considered to be part of the 'welfare state' as it developed throughout the 20th century. See Flora and Heidenheimer (1981); Castles (1998); Keman (2019). 